\title{
PENDIDIKAN AKHLAK DALAM POLA ASUH ORANG TUA
}

\section{Hasnawati}

Jurusan Tarbiyah STAIN Sjech M. Djamil Djambek

Jl. Raya Gurun Aur Kubang Putih Kabupaten Agam

Email: hasna.stain@gmail.com

\section{ABSTRAK}

Tulisan ini bermaksud mengkaji pola asuh orang tua berdasarkan perspektif pendidikan Islam terutama pendidikan akhlak. Bagaimanapun juga, semua pola asuh berdampak pada perilaku anak yang diasuhnya. Karena ada kecenderung berdampak itulah maka semua pola asuh dapat diintervensi oleh pesan-pesan moral, adab, watak, sikap dan akhlak tertentu. Dalam perspektif pendidikan akhlak/Islam, semua pola asuh pada dasarnya dapat diintervensi oleh sikap; 1) cinta kasih; 2) senang berdoa; 3) penuh rasa syukur; 4) gemar bersedekah; 5) senang berbagi kebahagiaan dengan orang lain; 6) selalu jujur dalam berkata maupun berbuat (tidak berdusta kepada orang lain); 7) berpegang teguh pada ajaran agama/Tuhan; 8) bersikap tegas namun tetap sopan dan beradab; 9) senantiasa memanfaatkan waktu luang secara bermakna dan 10) selalu memperhatikan hak-hak orang lain di samping sabar dalam menjalankan segala bentuk kewajiban/peraturan yang ditetapkan kepadanya. Sepuluh dimensi akhlakiah ini tergambar dalam pola asuh Rasul Muhammad saw saat mendidik anak, cucu serta seluruh umatnya.

Kata kunci: Pola asuh orang tua, Pendidikan akhlak, Agresifitas

\section{ABSTRACT}

This paper intends to study the pattern of parenting is based on the perspective of Islamic education, especially moral education. However, all have an impact on the parenting behavior of children who care. Because there is a tendency that it affects all the parenting to intervention by the messages morals, manners, character, attitude and a certain character. In the perspective of moral education (Islam, all parenting basically to intervention by the attitude; 1 ) love, 2) love to pray; 3) gratitude; 4) fond of charity; 5) happy to share happiness with others; 6) always honest in saying or doing (do not lie to others); 7) adherence to the teachings of the religion/God; 8) to be firm yet polite and civilized; 9) always make use of leisure time were significantly; and 10) always pay attention to the rights of people alongside another patient in carrying out any form of liability / regulations set him. The ten akblakiah dimension is reflected in parenting Mubammad Rasul while educating children, grandchildren and the whole community.

Keywords: Parenting parents, Moral education, Aggressiveness 


\section{PENDAHULUAN}

Keluarga merupakan lembaga pertama dalam kehidupan anak. Keluarga adalah tempat di mana anak mengawali belajar dan menyatakan diri sebagai mahluk sosial. Dalam keluarga umumnya anak berada dalam hubungan interaksi yang intim. Keluarga memberikan dasar pembentukan tingkah laku, watak, moral dan pendidikan anak (Kartono, 1992).

Orang tua merupakan pendidik utama dan pertama bagi anak-anak mereka, karena dari merekalah anak mula-mula menerima pendidikan. Bentuk pertama dari pendidikan terdapat dalam kehidupan keluarga. Orang tua dikatakan pendidik pertama karena dari merekalah anak mendapatkan pendidikan untuk pertama kalinya dan dikatakan pendidik utama karena pendidikan dari orang tua menjadi dasar perkembangan dan kehidupan anak di kemudian hari.

Orang tua adalah lingkungan pertama dan utama dalam kehidupan seorang anak. Hal ini akan mendasari perkembangan anak pada tahap berikutnya. Karenanya dibutuhkan pola asuh yang tepat agar anak tumbuh dan berkembang secara optimal. Citra diri senantiasa terkait dengan proses tumbuh kembang anak berdasarkan pola asuh dalam membesarkannya (Daryati R, 2009).

Mendidik anak dengan baik dan benar berarti menumbuhkembangkan totalitas potensi anak secara wajar. Potensi jasmaniah anak diupayakan tumbuh secara wajar melalui pemenuhan kebutuhan-kebutuhan jasmani, seperti pemenuhan kebutuhan sandang, pangan dan papan. Sedangkan potensi rohaniah anak diupayakan pengembangannya secara wajar melalui usaha pembinaan intelektual, perasaan dan budi pekerti.

Anak lahir dalam pemeliharaan orang tua dan dibesarkan dalam keluarga. Orang tua bertugas sebagai pengasuh, pembimbing, pemelihara dan sebagai pendidik terhadap anak-anaknya. Setiap orang tua pasti menginginkan anakanaknya menjadi manusia yang pandai, cerdas dan berakhlak. Akan tetapi banyak orang tua yang tidak menyadari bahwa cara mereka mendidik membuat anak merasa tidak diperhatikan, dibatasi kebebasannya, bahkan ada yang merasa tidak disayangi oleh orang tuanya. Perasaan-perasaan itulah yang banyak mempengaruhi sikap, perasaan, cara berpikir bahkan kecerdasan mereka.

Ada banyak faktor yang menyebabkan terjadinya kenakalan pada anakanak yang dapat menyeret mereka pada dekadensi moral. Selain dari pendidikan yang buruk di masyarakat juga kenyataan kehidupan yang pahit serta penuh dengan "kegilaan" menjadi sumber kejahatan dan kerusakan watak anak-anak. Oleh karena itu, jika para orang tua tidak dapat memikul tanggung jawab dan amanat yang diberikan pada mereka, dan tidak mengetahui faktor-faktor yang dapat menimbulkan kelainan pada anak-anak serta upaya penanggulangannya maka akan terlihat suatu generasi yang bergelimang dosa dan penderitaan dalam masyarakat. Hal ini sesuai dengan untaian hikmah dari hadis Nabi yang dikisahkan Anas ra. Berkata Rasulullah SAW "Apabila Allah menghendaki kebaikan pada suatu keluarga, dia memperdalamkan pengetahuan agama kepada mereka, menjadikan 
anak-anak mereka menghormati orang tua mereka, memberikan kemudahan pada kebidupan mereka, kesederhanaan dalam nafkeah mereka, dan memperlihatkan aib mereka sehingga mereka menyadarinya, lalu menghentikan perbuatannya. Namun apabila menghendaki sebaliknya, dia meninggalkan dan menelantarkan mereka." (HR. Daru Quthni dalam Nur dan Hafizh, 1988: 9).

Di kalangan remaja, aksi yang biasa dikenal sebagai tawuran pelajar/masal/geng motor merupakan hal yang sudah sering terjadi, bahkan cenderung dianggap biasa. Pelaku-pelaku tindakan aksi ini bahkan sudah mulai dilakukan oleh siswa-siswa di tingkat SLTP/SMP. Banyak pelajar terpaksa diamankan petugas gara-gara tawuran. Peristiwa tersebut banyak mendapat sorotan dan perhatian baik dari orang tua, pemerintah, pendidik serta psikolog karena ada gejala terus meningkatnya tingkah laku agresif pada anak.

Agresi itu sendiri menurut Murray (dalam Hall \& Lindzey, Psikologi kepribadian, 1993) didefinisikan sebagai suatu cara untuk melawan dengan sangat kuat, berkelahi, melukai, menyerang, membunuh, atau menghukum orang lain. Agresi adalah tindakan yang dimaksudkan untuk melukai orang lain atau merusak milik orang lain. Bentuk nyata agresivitas yang dilakukan anak-anak/remaja adalah maraknya perkelahian/tawuran antar pelajar yang sering membawa korban jiwa. Tawuran merupakan perilaku agresi dari seorang individu atau kelompok. Kini perilaku agresif dalam tawuran ini merupakan gejala yang bukan hanya lumrah terjadi di kalangan pelajar dan masyarakat namun mengarah ke gaya hidup remaja masa kini.

Keagresifan, sebagai gejala sosial dapat dipengaruhi oleh beberapa faktor yaitu; a) pengaruh keluarga; b) pengaruh subkultural. Dalam konteks pengaruh subkultural ini sumber agresi adalah komunikasi atau kontak langsung yang berulang kali terjadi antar sesama anggota masyarakat di lingkungan anak tinggal. Mengingat kondisi remaja yang masih labil, maka teman sebaya (peer group) sangat berperan dalam mewarnai perilaku remaja yang bersangkutan; c) modelling (vicarious learning), merupakan sumber tingkah laku agresi berikutnya yang secara tidak langsung didapat dari media masa, misalnya televisi, majalah, koran, video atau bioskop. Mengingat perilaku agresi merupakan hasil proses belajar dalam interaksi sosial maka tingkah laku agresi juga dipengaruhi oleh lingkungan sosial.

Perilaku agresif pun dapat dipengaruhi oleh lingkungan. Lingkungan keluarga merupakan lingkungan terdekat bagi remaja, sehingga keluarga juga merupakan sumber bagi timbulnya agresi. Salah satu faktor yang diduga menjadi sebab timbulnya tingkah laku agresif adalah kecenderungan pola asuh tertentu dari orang tua (child rearing) yang kurang memperhatikan aspek akhlak. Pola asuh orang tua merupakan interaksi antara orang tua dengan anaknya selama mengadakan pengasuhan. Pola asuh orang tua juga merupakan salah satu faktor yang mempunyai peranan penting dalam pembentukan kepribadian anak. Keluarga adalah lingkungan yang pertama kali menerima 
kehadiran anak. Keadaan kehidupan keluarga bagi seorang anak dapat dirasakan melalui sikap dari orang yang sangat dekat dan berarti baginya. Dengan kata lain, pola asuh orang tua akan mempengaruhi perilaku anaknya.

Perkembangan tingkah laku agresif pada anak dipengaruhi oleh orang tuanya melalui pengontrolan, pengalaman frustasi anak dan juga cara orang tua memberikan penguatan ataupun hukuman terhadap tingkah laku agresif. Anak belajar bertingkah laku agresif melalui imitasi atau model terutama dari orang tuanya, guru dan anak-anak lainnya.

Tulisan ini bermaksud mengkaji bahwa pola asuh orang tua berpengaruh terhadap pembentukan karakter anak. Anak bisa menjadi agresif pola asuh orang tua cenderung agresif. Dengan demikian asumsinya jika pola asuh orang tua itu sarat dengan muatan akhlak mulia maka anak kelak akan menjadi anak yang berakhlak mulia juga. Tema dalam tulisan ini dianalisis berdasarkan perspektif pendidikan Islam terutama pendidikan akhlak.

\section{PEMBAHASAN}

Masyarakat sebagai suatu lingkungan yang relatif besar diatur dalam suatu norma atau nilai serta dibatasi oleh suatu budaya tertentu. Kebudayaan dalam suatu tatanan masyarakat mengatur perilaku orang untuk hidup bermasyarakat, termasuk remaja. Remaja yang berada pada kondisi ingin mencari nilai-nilai baru dalam kelompoknya memungkinkan untuk bertolak belakang dengan norma-norma masyarakat yang sudah mapan. Masa remaja ditandai dengan datangnya masa puber. Bersamaan dengan itu terjadi pula pertumbuhan fisik, tetapi juga timbul gejolak-gejolak.

Timbulnya gejolak pada masa remaja ini karena remaja berada pada masa transisi. Masa remaja adalah masa di mana periode anak-anak sudah terlewati namun ia belum diterima sebagai manusia dewasa. Pada masa-masa seperti ini remaja senang mencoba hal-hal baru, sehingga ia mulai sering meninggalkan rumah untuk bergabung dengan teman-temannya (peer group). Dalam peer group anak-anak yang berkumpul berasal dari berbagai lingkungan keluarga maka akan terjadi pula pertukaran karakteristik psikologis maupun sosial. Di samping tumbuhnya solidaritas yang kuat di antara sesama teman juga akan muncul rasa bangga akan kelompoknya (in group feeling) yang sangat kuat. Peer group terbentuk karena adanya kesesuaian aspek-aspek tertentu di antara anggota-anggotanya. Anggota peer group ini dapat terdiri dari laki-laki maupun perempuan. Oleh sebab itu, terjadi pula berbagai kegiatan yang saling mempengaruhi. Salah satu pengaruh yang dapat muncul adalah terjadinya perilaku agresif. Dalam kehidupan sehari-hari istilah agresif sering digunakan oleh masyarakat. Di dalam istilah yang digunakan tersebut kebanyakan di dalamnya mengandung akibat atau kerugian bagi orang lain maupun dirinya sendiri. Menurut Sears (dalam Stewart dan Koch, 1983) tingkah laku agresi ini pada dasarnya merupakan tingkah laku yang bermaksud melukai, menyakiti atau merugikan orang lain. Herbert (1978) berpandangan bahwa tingkah laku agresi 
merupakan suatu tingkah laku yang tidak dapat diterima secara sosial, karena menyebabkan luka fisik, psikis pada orang lain, atau yang bersifat merusak benda. Baron (1977) mengatakan bahwa agresif itu merupakan tingkah laku individu yang ditujukan untuk melukai atau mencelakakan individu lain.

Sikap agresif terjadi pada setiap individu, termasuk juga remaja. Masa remaja merupakan masa transisi dari masa kanak-kanak ke masa dewasa. Meskipun sampai saat ini belum ada kesepakatan para ahli tentang batasan remaja baik melalui usia dan kapan mulai serta berakhirnya, akan tetapi masa remaja ini ditandai dengan datangnya masa puber, adanya perkembangan fisik yang maksimal dan sudah mampu berreproduksi. Bersamaan dengan pertumbuhan fisik tersebut berkembang pula aspek psikologis dan aspek sosialnya. Remaja yang masih dalam proses perkembangan tersebut mempunyai kebutuhan-kebutuhan pokok terutama kebutuhan rasa aman, rasa sayang, dan kebutuhan rasa harga diri. Zakiah Daradjat (1989) mengatakan bahwa setiap orang mempunyai kebutuhan-kebutuhan yang perlu dipenuhi, jika tidak dipenuhi akan terjadi goncangan. Pada prinsipnya manusia ingin memenuhi kebutuhan dengan cara yang ia pilih. Apabila kebutuhan itu tidak terpenuhi maka individu (remaja) akan mengalami suatu problema. Kemungkinan remaja akan mengalami frustrasi atau perilaku yang dapat merugikan diri sendiri ataupun orang lain. Selanjutnya, situasi frustrasi akan membuat orang marah dan akan memperbesar kemungkinan mereka melakukan tindakan agresi.

Anak merupakan anugerah termahal bagi orang tua. Banyak orang tua yang mengharapkannya tapi tak kunjung diberi, sementara banyak juga orang tua yang dengan mudah memperolehnya. Tapi, jangan pula merasa bangga dengan hadirnya anak, jika kita tak mampu membekalinya dengan pendidikan yang benar sesuai ajaran Islam. Karena, selain anugerah, anak juga merupakan amanah "berat" yang dititipkan Allah kepada orang tuanya, terlebih lagi di tengah-tengah merosotnya nilai-nilai etika, moral dan gencarnya serangan permisifisme (budaya serba boleh) melalui media elektronik. Dengan demikian tanggungjawab orang tua menjadi kian berat.

Anak adalah anugerah. Di dalam al-Qur'an dikatakan sebagai perhiasan hidup, "Harta dan anak-anak adalah perbiasan kebidupan dunia..." (QS. al-Kahfi: 46). Artinya, jika hidup kita tanpa perhiasan, semuanya akan terasa suram. Untuk itu kita patut bersyukur atas nikmat Allah yang dititipkannya melalui anak-anak kita. Rasa syukur itu dapat kita wujudkan dengan mengasuh dan mendidik mereka berlandaskan fitrah dan kasih sayang. Selain sebagai anugerah, anak diberikan kepada orang tuanya sebagai amanah "berat" untuk dipelihara, dididik dan dibina agar berkualitas dan tangguh. Seperti diperintahkan dalam al-Qur'an yang artinya, "Dan hendaklah takut kepada Allah orang-orang yang seandainya meninggalkan di belakang mereka anak-anak yang lemah, yang mereka khawatir terhadap (kesejabteraan) mereka. Oleh sebab itu hendaklah mereka bertakwa kepada Allah dan bendaklah mereka mengucapkan perkataan yang benar" (QS. an-Nisâ: 9). 
Mengenal pola asuh orang tua dan karakteristik kepribadian setiap individu yang unik dan berbeda-beda merupakan hal susah-susah gampang. Hal ini disebabkan oleh banyak faktor yang mempengaruhinya, salah satunya adalah keluarga. Keluarga merupakan lingkungan sosial terkecil, namun memiliki peran yang sangat besar dalam mendidik dan membentuk kepribadian seseorang individu. Struktur dalam keluarga terdiri atas ayah dan ibu, kemudian bertambah dengan adanya anggota lain yaitu anak. Dengan demikian, terjadi hubungan segitiga antara orang tua-anak, yang kemudian membentuk suatu hubungan yang berkesinambungan. Orang tua dan pola asuh memiliki peran yang besar dalam menanamkan dasar kepribadian yang ikut menentukan corak dan gambaran kepribadian seseorang setelah dewasa kelak.

Orang tua memiliki cara dan pola tersendiri dalam mengasuh dan membimbing anak. Cara dan pola tersebut tentu akan berbeda antara satu keluarga dengan keluarga lainnya. Pola asuh orang tua merupakan gambaran tentang sikap dan perilaku orang tua dan anak dalam berinteraksi, berkomunikasi selama mengadakan kegiatan pengasuhan. Dalam kegiatan memberikan pengasuhan ini, orang tua akan memberikan perhatian, peraturan, disiplin, hadiah dan hukuman, serta tanggapan terhadap keinginan anaknya. Sikap, perilaku, dan kebiasaan orang tua selalu dilihat, dinilai, dan ditiru oleh anaknya yang kemudian semua itu secara sadar atau tidak sadar akan diresapi kemudian menjadi kebiasaan pula bagi anak-anaknya.

Penelitian yang telah dilakukan oleh Baumrind (Santrock, 1998) mengenai perkembangan sosial dan proses keluarga telah dilakukan sejak pertengahan abad ke 20. Ia kemudian membagi pola asuh orang tua yang berkaitan dengan perilaku remaja ke dalam tiga pola yang berbeda diantaranya authoritarian atau otoriter, permissive (permisif) dan authoritative atau demokratis.

Menurut Nashori (2008), sejauh ini, di Indonesia khususnya, belum banyak penelitian tentang profil orang tua yang sukses dalam mendidik anak. Beberapa penelitian korelasional telah dilakukan untuk mengungkapkan pola asuh orang tua (seperti dari Dayakisni, 1977; Krisnawaty, 1986; Winarto, 1990; Wismantono, 1995; Wulan, 2000; Setiawan, 1997; Roswita, 2000; Dalimunthe, 2000; Cahyaningrum, 2000; Hapsari, 2000; Mustaqim, 2000; Kurnia, 2000; Endahwati, 2001; Saptasari, 2001; Wibowo, 2002; Furqon, 2002; Mayaningrum, 2002) dan diketahui bahwa pola asuh demokratis/autoritatif dapat menjadikan anak memiliki kecenderungan pro sosial (1977). Anak juga berkembang dalam hal kompetensi sosial (Dalimunthe, 2000), prestasi belajar (Roswita, 2000; Mustaqim, 2000; Furqon, 2002), sikap asertif (2001), penyesuaian diri (Mayaningrum, 2002), ketaatan pada peraturan lalu lintas (Wismantono, 1995), kepribadian wiraswasta (Winarto, 1990). Mereka lebih tinggi dibandingkan dengan anak-anak yang memperoleh pola asuh otoriter maupun permisif dari orang tuanya. Di samping itu, penelitian tersebut juga menunjukkan bahwa bola asuh demokratis dapat menjadikan anak memiliki prokrastinasi (Wulan, 2000) 
dan depresi (Saptasari, 2001) yang lebih rendah dibandingkan dengan anak yang diasuh melalui pola asuh otoriter dan permisif.

Penelitian lain yang dilakukan oleh Bloom (Psikologika, 1999) menunjukkan bahwa bintang-bintang olahraga, seni, matematika, musik, yang sukses dididik sebelumnya oleh orang tuanya dengan penuh perhatian, dan selanjutnya didampingi oleh pelatih-pelatih yang profesional. Sebagai contoh, bintang cilik, Sherina awalnya dilatih oleh orang tuanya dalam bernyanyi. Untuk memperbaiki dan meningkatkan kualitas cara bernyanyinya ia dididik oleh seorang profesional yang bernama Elfa Secioria (Kedaulatan Rakyat, 12 Oktober 2001).

Dalam mengasuh anaknya, orang tua dipengaruhi oleh budaya yang ada di lingkungannya. Di samping itu, orang tua juga diwarnai oleh sikapsikap tertentu dalam memelihara, membimbing, dan mengarahkan putraputrinya. Sikap tersebut tercermin dalam pola pengasuhan kepada anaknya yang berbeda-beda, karena orang tua mempunyai pola pengasuhan tertentu. Penggunaan pola asuh tertentu ini memberikan sumbangsih dalam mewarnai perkembangan perilaku tertentu pada anaknya. Salah satu perilaku yang muncul dapat berupa perilaku agresif. Pola asuh merupakan sikap orang tua dalam berinteraksi dengan anak-anaknya. Sikap orang tua ini meliputi cara orang tua memberikan aturan-aturan, hadiah maupun hukuman, cara orang tua menunjukkan otoritasnya, dan cara orang tua memberikan perhatian serta tanggapan terhadap anaknya.

\section{Beberapa Pengaruh Pola Asuh Orang Tua terhadap Anak}

Perkembangan fisik dan psikis anak banyak dipengaruhi oleh cara penanganan orang tua. Peranan orang tua itu memberikan lingkungan yang memungkinkan anak dapat menyelesaikan tugas-tugas perkembangannya, terutama pada masa awal (kanak-kanak) sampai masa remaja. Keluarga merupakan kelompok sosial yang pertama di mana anak dapat berinteraksi. Pengaruh keluarga dalam pembentukan dan perkembangan kepribadian anak sangat besar artinya. Keluarga yang dilandasi kasih sayang, sangat penting bagi anak supaya anak dapat mengembangkan tingkah laku sosial yang baik. Bila kasih sayang tersebut tidak ada, maka seringkali anak akan mengalami kesulitan dalam hubungan sosial, dan kesulitan ini akan mengakibatkan berbagai macam kelainan tingkah laku sebagai upaya kompensasi dari anak. Sebenarnya, setiap orang tua itu menyayangi anaknya, akan tetapi manifestasi dari rasa sayang itu berbeda-beda dalam penerapannya. Perbedaan itu akan nampak dalam pola asuh yang diterapkan orang tuanya.

Menurut Stewart dan Koch (1983), orang tua yang menerapkan pola asuh otoriter mempunyai ciri antara lain: kaku, tegas, suka menghukum, kurang ada kasih sayang serta kurang simpatik. Orang tua memaksa anakanak untuk patuh pada nilai-nilai mereka, serta mencoba membentuk tingkah laku sesuai dengan tingkah lakunya sendiri serta cenderung mengekang 
keinginan anak. Orang tua tidak mendorong serta memberi kesempatan kepada anak untuk mandiri dan jarang memberi pujian. Hak anak dibatasi tetapi dituntut tanggung jawab seperti anak dewasa.

Orang tua yang otoriter cenderung memberi hukuman terutama hukuman fisik. Orang tua yang otoriter amat berkuasa terhadap anak, memegang kekuasaaan tertinggi serta mengharuskan anak patuh pada perintahperintahnya. Dengan berbagai cara, segala tingkah laku anak dikontrol dengan ketat. Sutari Imam Barnadib (1986) mengatakan bahwa orang tua yang otoriter tidak memberikan hak anaknya untuk mengemukakan pendapat serta mengutarakan perasaan-perasaannya, sehingga pola asuh otoriter berpeluang untuk memunculkan perilaku agresif.

Berdasarkan teori yang disampaikan pada bagian depan, terlihat bahwa semakin dihadang kebutuhan seseorang untuk mencapai tujuan akan menjadikan prakondisi agresi semakin tertekan dan mengakumulasi sehingga muncul perilaku agresi. Adanya hubungan pola asuh otoriter dengan keagresifan remaja itu sejalan dengan apa yang dikemukakan oleh Baumrind bahwa keluarga yang suka melakukan hukuman terutama hukuman fisik menyebabkan anak mempunyai sifat pemarah dan untuk sementara ditekan karena norma sosial (barier), namun suatu saat akan meluapkan amarahnya sebagai perilaku yang agresif. Tentang hubungan pola asuh otoriter dengan agresifitas pada anak laki-laki dan perempuan menunjukkan adanya perbedaan.

Tingkah laku agresif pada anak laki-laki tetap stabil pada setiap masa perkembangannya, tetapi untuk anak perempuan tingkah laku agresif ini akan semakin berkurang. Berkurangnya perilaku agresif pada anak perempuan ini barangkali karena norma yang ada dalam masyarakat mencela perbuatan agresif bagi anak perempuan. Di samping norma seperti diutarakan di atas, dapat juga karena faktor budaya. Perempuan lebih sering menampilkan perilaku yang lembut, sehingga perilaku agresif nampaknya bukan milik perempuan. Laki-laki dianggap biasa untuk bertindak agresif dibandingkan anak perempuan. Anak perempuan secara psikologis lebih dapat menahan emosi. Artinya, semakin ditekan orang tua akan semakin menurut atau hanya menangis dan mengurung diri dalam kamar.

Baumrind \& Black (dalam Hanna Wijaya, 1986) mengemukakan bahwa teknik-teknik asuhan orang tua yang demokratis dapat menumbuhkan keyakinan dan kepercayaan diri maupun mendorong tindakan-tindakan mandiri membuat keputusan sendiri akan berakibat munculnya tingkah laku mandiri yang bertanggung jawab. Stewart dan Koch (1983) menyatakan bahwa orang tua yang demokratis memandang sama kewajiban dan hak antara orang tua dan anak. Secara bertahap orang tua memberikan tanggung jawab bagi anak-anaknya terhadap segala sesuatu yang diperbuatnya sampai mereka menjadi dewasa. Mereka selalu berdialog dengan anak-anaknya, saling memberi dan menerima, selalu mendengarkan keluhan-keluhan dan pendapat anak-anaknya. Dalam bertindak, mereka selalu memberikan alasannya kepada anak, mendorong 
anak saling membantu dan bertindak secara objektif, tegas tetapi hangat dan penuh pengertian. Menurut Hurlock (1976) pola asuhan demokratik ditandai dengan ciri-ciri bahwa anak-anak diberi kesempatan untuk mandiri dan mengembangkan kontrol internalnya, anak diakui keberadaannya oleh orang tua, anak dilibatkan dalam pengambilan keputusan.

Sutari Imam Barnadib (1986) mengatakan bahwa orang tua yang demokratis selalu memperhatikan perkembangan anak, dan tidak hanya sekedar mampu memberi nasehat dan saran tetapi juga bersedia mendengarkan keluhankeluhan anak berkaitan dengan persoalan-persoalannya. Pola asuhan demokratik memungkinkan semua keputusan merupakan keputusan anak dan orang tua.

Lewin, Lippit, dan White (dalam Gerungan, 1987) mendapatkan keterangan bahwa kelompok anak laki-laki yang diberi tugas tertentu di bawah asuhan seorang pengasuh yang berpola demokratis tampak bahwa tingkah laku agresif yang timbul adalah dalam taraf sedang. Kalau pengasuh kelompok itu adalah seorang yang otoriter maka perilaku agresif mereka menjadi tinggi atau justru menjadi rendah.

Hasil yang ditemukan oleh Lewin diteruskan oleh Meuler (Gerungan, 1987) dalam penelitiannya dengan menemukan hasil bahwa anak-anak yang diasuh oleh orang tua yang otoriter banyak menunjukkan ciri-ciri adanya sikap menunggu dan menyerah segala-galanya pada pengasuhnya. Di samping sikap menunggu itu terdapat juga ciri-ciri keagresifan, kecemasan dan mudah putus asa. Baldin (dalam Gerungan, 1987) membandingkan antara keluarga yang berpola demokratis dengan yang otoriter dalam mengasuh anaknya. Ia mengatakan bahwa asuhan dari orang tua yang demokratis menimbulkan ciri-ciri berinisiatif, berani, lebih giat, dan lebih bertujuan. Sebaliknya, semakin otoriter orang tuanya makin berkurang ketidaktaatan anak, bersikap menunggu, tak dapat merencanakan sesuatu, daya tahan kurang, dan menunjukkan ciri-ciri takut. Jadi setiap pola asuh orang tua akan berpengaruh terhadap anak asuhannya dalam perilaku tertentu, misalnya terjadinya keagresifan pada anak.

Dalam pola asuh demokratis, hampir segala kebutuhan pokok anak dapat diakomodasikan dengan wajar. Kebutuhan pokok manusia yang terpenuhi akan menimbulkan suasana psikologis maupun sosial yang menggembirakan. Dalam pola asuh demokratis komunikasi dapat berjalan wajar dan lancar sehingga setiap persoalan yang dialami anak dalam keluarga dapat disalurkan dalam suasana dialogis. Dengan demikian, stres dan frustrasi yang merupakan prakondisi agresifitas tidak muncul.

Menurut Barnadib (1986), karena dalam keluarga yang diasuh dengan pola asuh demokratis sifat hubungan anak dengan orang tuanya harmonis, mempunyai sifat terbuka dan bersedia mendengarkan pendapat orang lain, maka ia mampu menyesuaikan diri dengan lingkungannya secara baik dan emosinya stabil. Kestabilan ini penting peranannya agar anak selalu sadar akan tindakan yang akan dilakukannya. Dalam keluarga demokratis anak selalu 
merasakan hangatnya suasana dan tidak melihat kekejaman-kekejaman yang ada di rumah. Bagaimanapun juga anak dalam keluarga selalu melihat interaksi dan perlakuan orang tuanya, anak sampai pada usia remaja lebih banyak dipengaruhi oleh perlakuan orang tuanya. Pengaruh-pengaruh yang diterima oleh anak dalam suasana keluarga yang semacam ini tentu akan berpengaruh baik dan suasana yang berpola asuh demokratis ini paling baik memberikan pengaruh positif terhadap perkembangan anak.

Pola pembinaan anak yang berada dalam suasana keluarga demokratis, permusuhan atau kebencian serta ketidaksenangan di antara anggota keluarga diungkap secara terbuka. Backman (1986) mengemukakan bahwa semakin demokratis suatu keluarga akan semakin bebas setiap anggota keluarga untuk mengungkapkan hal-hal yang tidak disukainya maupun mengekspresikan halhal yang disukainya dalam interaksinya dengan masing-masing anggota keluarga. Di samping itu, remaja yang orang tuanya menggunakan pola asuh demokratis memiliki hubungan yang lebih harmonis antara anak dengan anak dan dengan orang tua. Hal ini tentu saja akan mempunyai pengaruh yang lebih baik dalam perkembangan jiwa anak. Dengan demikian, masuk akal ketika pola asuh demokratis tidak mempunyai hubungan/tidak berpengaruh terhadap munculnya perilaku agresif remaja.

Tipe orang tua yang mempunyai pola asuh permisif cenderung selalu memberikan kebebasan pada anak tanpa memberikan kontrol sama sekali. Anak sedikit sekali dituntut untuk suatu tangung jawab, tetapi mempunyai hak yang sama seperti orang dewasa. Anak diberi kebebasan untuk mengatur dirinya sendiri dan orang tua tidak banyak mengatur anaknya. Menurut Spock (1982) orang tua permisif memberikan kepada anak untuk berbuat sekehendaknya dan lemah sekali dalam melaksanakan disiplin pada anak. Hurlock (1976) mengatakan bahwa pola asuhan permisif bercirikan adanya kontrol yang kurang, orang tua bersikap longgar atau bebas, bimbingan terhadap anak kurang. Ciri pola asuh ini adalah semua keputusan lebih banyak dibuat oleh anak daripada orang tuanya.

Sutari Imam Barnadib (1986) menyatakan bahwa orang tua yang permisif, kurang tegas dalam menerapkan peraturan-peraturan yang ada, dan anak diberikan kesempatan sebebas-bebasnya untuk berbuat dan memenuhi keinginannya. Secara teoretik hubungan pola asuh permisif dengan agresifitas mestinya lebih rendah dibandingkan dengan hubungan pola asuh otoriter dengan agresifitas. Namun, kenyataan di lapangan mengatakan lain, yakni pola permisif justru mempunyai hubungan yang lebih besar bagi munculnya agresifitas. Mengapa demikian? Beberapa kemungkinan ditampilkan. Salah satu di antaranya adalah bahwa ketika manusia semakin direndahkan martabatnya dengan tidak menggubris seluruh perbuatannya maka ia akan mencari perhatian dengan cara menampilkan perbuatan yang negatif yang langsung dapat mencemarkan nama baik keluarganya. Jika cara yang ditempuh individu itu 
mendapat penguatan maka ia akan lebih sering melakukan tindakan yang negatif, dalam konteks ini adalah perilaku agresif.

Berkaitan dengan pola asuh permisif ini, Barnadib (1986) menyatakan bahwa tindakan negatif ini berupa anak tidak mengenal tata tertib, sulit dipimpin dan tidak taat pada peraturan. Pola asuh permisif dapat menyebabkan perilaku agresif bagi anak asuhnya.

Beberapa pola asuh orang tua yang dianggap memiliki dampak terhadap perilaku anak yaitu; 1) authoritarian. Biasanya, orang tua cenderung memiliki sikap yang rendah dalam "acceptace", namun kontrolnya tinggi, suka menghukum secara fisik, bersikap mengomando (mengharuskan/memerintah anak untuk melakukan sesuatu tanpa kompromi, bersikap kaku, cenderung emosional dan bersikap menolak. Dampaknya anak mudah tersinggung, penakut, pemurung, tidak bahagia, mudah terpengaruh, mudah stres, tidak mempunyai arah masa depan yang jelas dan tidak bersahabat; 2) permissive. Biasanya, orang tua cenderung memilliki sikap "acceptance" yang tinggi namun kontrolnya rendah, memberikan kebebasan terhadap anak untuk menyatakan dorongan keinginannya. Dampaknya anak cenderung bersikap impulsif dan agresif, suka memberontak, kurang memiliki rasa percaya diri dan pengendalian diri,suka mendominasi, tidak jelas arah hidupnya, rendah prestasinya; 3) authoritative. Biasanya, orang tua cenderung memiliki sikap "acceptance" dan control yang tinggi, bersikap responsif terhadap kebutuhan anak, mendorong anak untuk menyatakan pendapat atau pertanyaan, memberikan penjelasan tentang dampak perbuatan yang baik dan buruk. Dampaknya, anak cenderung bersikap bersahabat, memiliki rasa percaya diri, mampu mengendalikan diri, bersikap sopan, mau bekerja sama, memiliki rasa ingin tahunya yang tinggi, mempunyai arah hidup yang jelas, berorientasi terhadap prestasi; 4) domination (dominasi), Biasanya, orang tua cenderung memiliki sikap mendominasi anak. Dampaknya, anak cenderung bersikap sopan dan sangat berhati-hati, pemalu, penurut, inferior dan mudah bingung, tidak dapat bekerja sama; 5) submission (penyerahan). Biasanya, orang tua cenderung memiliki sikap senantiasa memberikan sesuatu yang diminta anak berperilaku semaunya di rumah. Dampaknya, anak menjadi tidak patuh, tidak bertanggung jawab, agresif, teledor, bersikap otoriter dan terlalu percaya diri; 6) punitiveness (overdiscipline). Biasanya, orang tua cenderung memiliki sikap mudah memberikan hukuman, menanamkan kedisiplinan secara keras. Dampaknya, anak menjadi impulsif, tidak dapat mengambil keputusan, nakal, sikap bermusuhan/agresif (Yusuf, 2005: 50-51).

\section{Pendidikan Akhlak dalam Pola Asuh Orang Tua}

Memberikan teladan adalah metoda paling jitu dalam pendidikan anak. Karenanya memperkenalkan pribadi Nabi Muhammad SAW sejak dini akan menjadi fondasi penting pembangunan akhlak Islam pada anak-anak. Jadikanlah sosok Nabi itu hidup dalam benak mereka dan sangat mereka cintai. Tak ada 
pribadi yang lebih indah budi pekertinya selain dari Nabi Muhammad SAW. Dan engkau (Mubammad) sungguh berakhlaq mulia (QS. al Kalam [86]: 4).

Dengan menghadirkan pribadi Nabi dalam keseharian anak-anak, mereka akan lebih mudah melaksanakan akhlak islami, sebab ada sosok yang menjadi panutan di hadapan mereka. Menghadirkan sosok Nabi misalnya dapat dilakukan dengan mengisahkan betapa beliau pribadi yang penyayang kepada sesama manusia, betapa beliau amat penyantun (hilm), betapa beliau pemberani dalam membela kebenaran, betapa beliau taat kepada Allah dengan tekun beribadah dan lain-lain.

Rasulullah SAW dalam sebuah riwayat pernah berkata, "Sesungguhnya, setiap anak yang dilabirkan ke dunia ini dalam keadaan suci (fithrah, Islam). Dan, karena kedua orang tuanyalah, anak itu akan menjadi seorang yang beragama Yabudi, Nasrani, atau Majusi." Hadis tersebut menegaskan bahwa sesungguhnya setiap anak yang dilahirkan itu laksana sebuah kertas putih yang polos dan bersih. Ia tidak mempunyai dosa dan kesalahan serta keburukan yang membuat kertas itu menjadi hitam. Namun, karena cara mendidik orang tuanya, karakter anak bisa berwarni-warni.

Jamal Abdurrahman Athfal al-Muslimin, dalam kaifa Rabbâhum an-Nabiy alAmin, menjelaskan tentang pelbagai cara Rasulullah mendidik anak. Dapat disimpulkan bahwa jenjang pendidikan terhadap anak antara lain; a) anak sejak dari pembuahan sampai usia 3 tahun; b) anak usia 4 tahun sampai dengan 10 tahun; c) anak usia 10 tahun sampai dengan 14 tahun; d) anak usia 15 tahun sampai 18 tahun. Namun Abdullah Nashih Ulwan, dalam sebuah kitab yang berjudul Tarbiyat al-Awlad fi al-Islam (Pendidikan Anak Menurut Islam) menempatkan pernikahan sebagai prasyarat untuk menyelenggarakan pendidikan anak secara islami. Oleh karena itu, ada 5 jenjang pendidikan/bimbingan, yaitu;

\section{Pernikahan}

Pernikahan adalah awal mula terjadinya hubungan dan interaksi antara seorang suami dan istri dalam melanjutkan garis keturunan. Pernikahan itu tidak terbatas pada hubungan ragawi antara seorang pria dan wanita belaka. Hal ini lebih menyingkap tetang makna pernikahan dalam rangka keberadaan atau eksistensi manusia, menyangkut kemaslahatan hidup pasangan suami istri. Sebaik-baik pertimbangan menikahi wanita adalah karena keberagamaan, kesalihan, ketakwaan dan kepatuhannya kepada Allah. "Rasulullah SAW bersabda, "Piliblah umtuk (meletakkan) benih (keturunanmu) pada tempat yang baik (shalihah)!" (dari Aisyah diriwayatkan oleh Daruquthni). Suami juga harus memperhatikan pengetahuan yang dimiliki isterinya agar mengatur rumah dan mendidik anak dengan baik. Oleh karena itu, Rasulullah SAW memuji wanitawanita Quraisy karena sifat mereka yang penyayang terhadap anak-anak mereka dan perhatian terhadap suami mereka, "Sebaik-baik wanita penunggang onta adalah wanita salihah dari kaum Quraisy. Paling sayang terhadap anak-anak mereka dan paling perhatian terhadap suami mereka (dari Abu Hurairah diriwayatkan oleh Bukhari). 
2. Usia Sejak Pembuahan sampai Usia 3 Tahun.

Nabi Muhammad SAW menganjurkan kepada kaum Muslimin untuk selalu berdo'a sebelum bersetubuh. Seperti pada hadis yang diriwayatkan oleh Bukhari, "Jika kaliam mendatangi istrimu untuk bersetubub maka berdoalab:" Ya Allah jaubkan kami dari setan dan jaubkanlah setan dari anak-anak yang Engkau berikan kepada kami. "Maka jika dari bubungan itu labir seorang anak, setan selamanya tidak. berani menggodanya. "(HR Bukhari).

Nabi Muhammad SAW. juga mendoakan calon bayi yang masih dalam perut. Seorang ibu yang sedang mengandung harus banyak berdzikir, membaca al-Quran, suara yang terdengar pada janin dapat meningkatkan kecerdasan otaknya. Nabi Membacakan dzikir-dzikir untuk keselamatan bayi. Nabi Muhammad SAW mengadzani bayi ketika lahir pada telinga kanannya. Dari Abi Rafi, sesungguhnya ia berkata, "Sesunggubnya aku melihat Rasulullab mengumandangkan adzan pada telinga Hasan bin Ali ketika Fatimah melabirkannya," (HR. Abu Dawud dan At-Turmudzi).

Nabi mengadakan aqiqah dan berwasiat kepada umatnya untuk aqiqah ketika seorang anak lahir. Bila dia laki-laki aqiqah dengan dua kambing dan bila yang lahir wanita maka aqiqah dengan satu kambing. Nabi bersabda,"Setiap anak. itu tergadaikan sebab aqiqabnya. Hewan tersebut disembelib darinya pada hari ketujub (dari kelahirannya) dan bayi itu dipotong rambutnya dan ia diberi nama." (HR. an-Nasa'i, Ibnu Majah, dan Turmudzi). Dengan aqiqah ini ada makna rasa syukur, sedekah, berbagi kebahagiaan dengan orang lain.

Nabi Muhammad SAW, memberikan nama pada anak-anak dengan nama yang paling baik dan indah, nama yang baik akan menjadi doa kepada anaknya. Nabi Muhammad SAW menyuruh supaya rambut anak dipotong pada hari ketujuh, membersihkannya dan menghilangkan penyakit darinya. Nabi Muhammad SAW bermain bersama anak kecil dengan penuh kecintaan, bergurau dengan cara halus bersama anak-anak dalam bentuk ucapan maupun perilaku. Nabi Muhammad SAW memperhatikan khitan dan menganggapnya sebagai sunah fitrah. Nabi Muhammad SAW mengajari anak-anak cara-cara berpakaian yang rapi. Nabi Muhammad SAW Memberikan hadiah kepada anakanak dan beliau mengusap kepala mereka. Menyempatkan diri bermain bersama anak kecil. Nabi SAW menganjurkan orang tua untuk selalu jujur terhadap anak dan tidak berdusta kepadanya.

3. Pada Anak Usia Empat sampai Sepuluh Tahun

Pada saat ini orang tua hendaknya menjadi teman bagi anak, agar ia belajar dari dirinya di mana mengajari anak adalah kewajiban orang tua. Ini nasihat Nabi kepada anak kecil, "Wahai anak kecil aku akan mengajarimu beberapa kalimat, jagalah Allah maka Allah akan menjagamu, jagalah Allah maka engkau akan menemukan-Nya dihadapanmu, jika engkau meminta maka mohonlah kepada Allah, ketahuilab bahwa andaikata umat berkumpul untuk memberikan sesuatu yang bermanfaat kepadamu, maka mereka tidak akan mampu memberikan manfaat kepadamu kecuali 
sesuatu itu telah ditetapkan oleh Allah untuk.mu, Dan andaikata mereka berkumpul untuk. membahayakanmu, maka tidak akan membahayakanmu kecuali sesuatu itu telah ditetapkan oleh Allah atas kamu, pena-pena telah diangkat dan lembaran-lembaran telah kering"(HR. Turmudzi dan Ahmad).

Intinya, Nabi SAW senantiasa mengajak anak-anak untuk berahlak mulia. Nabi SAW minta izin kepada anak-anak bila ada kaitannya dengan hak-hak mereka. Nabi SAW mengajari shalat kepada anak, ketika berusia tujuh tahun dan memukul mereka karena meninggalkan shalat ketika berumur 10 tahun.

4. Anak Usia Sepuluh sampai Empat belas Tahun

Nabi SAW mengajak anak-anak untuk segera tidur setelah shalat isya, memisahkan tempat tidur anak-anak setelah mereka berusia sepuluh tahun. Nabi bersabda, "Perintablah anak-anak kalian untuk shalat pada umur tujub tahun, dan pukullah mereka karena meninggalkannya pada usia sepulub tabun, dan pisabkan tempat tidur mereka, jika salah satu dari kalian telah menikabkan budaknya atau pelayannya maka janganlah dilihat auratnya. Sesunggubnya anggota bagian bawah dari pusat sampai lutut adalah auratnya" (HR. Abu Dawud).

Nabi SAW membiasakan anak-anak untuk menjaga pandangan dan auratnya. Nabi SAW tidak pernah memukul anak-anak selamanya, tetapi beliau menjelaskan prinsip-prinsip dasar dan aturan dalam memukul. Kaidah-kaidanya adalah sebagai berikut: 1) pukulan tidak boleh diberikan sebelum usia sepuluh tahun; 2) pukulan boleh sedikit diberikan pada anggota tubuh yang memungkinkan; 3) batas maksimal hukuman pukulan hanya sepuluh kali itupun hanya kepada anak yang baligh dan mukallaf; 4) dan jangan memukul terlalu keras sehingga sampai terangkat ketiak; 5) dan jangan pada tempat sensitif, seperti wajah atau kepala.

Nabi SAW menyuruh anak-anak untuk duduk bersama ulama dan berperilaku sopan terhadap mereka, Rasulullah bersabda, "Sesunggubnya Luqman berkata kepada putranya, wahai anakku, bergaullah bersama ulama, dengarkanlah ucapan mereka, karena sesunggunya Allah menghidupkan hati yang mati dengan cahaya hikmah sebagaimana Allah menghidupkan bumi yang mati dengan bujan yang lebat" (HR. Thabrani).

Nabi SAW mengajari anak-anak etika untuk minta izin. Nabi bersabda," Hai orang-orang beriman, hendaklah budak-budak (lelaki dan wanta) yang kamu miliki, dan orang-orang yang belum baliqh di antara kamu, meminta izin kepada kamu tiga kali (dalam satu hari) yaitu sebelum sembahyang subuh, ketika kamu menanggalkan pakaian luarmu di tengah hari dan sesudah sembahyang isya, (itulab) tiga aurat bagi kamu. Tidak ada dosa atasmu dan tidak pula atas mereka selain dari tiga waktu itu. Mereka melayani kamu sebagaian kamu (ada keperluan) kepada sebagian (yang lain), demikianlah Allah menjelaskan ayat-ayat bagi kamu. Dan Allah Maha Mengetahui lagi Maha Bijaksana" (QS. An-Nur [24]: 58-59).

Nabi berwasiat tentang anak-anak perempuan, Nabi bersabda, "Barang siapa yang mempunyai tiga anak perempuan, kemudian ia sabar atas keberadaan mereka, 
baik sengsara dan bahagia mereka, maka Allab akan memasukekanya kedalam surga dengan mendapat keutamaan rabmat Allab terbadap mereka."Seorang laki-laki berkata;"Kalau dua anak perempuan wahai Rasulullab?" Nabi menjawab; "Demikian pula dua anak perempuan." Laki-laki itu berkata: "Kalau seorang anak perempuan wahai Rasulullab?" Nabi menjawab; 'Demikian pula seorang anak perempuan." (HR Ahmad).

Nabi saw menghukum dosa kepada orang yang menyia-nyiakan hak mereka dalam pemberian nafkah dan pendidikan. Nabi SAW bersabda; "Cukuplah dosanya bagi seseorang yang menyia-nyiakan orang yang berhak diberi nafkah darinya." (HR. Abu Dawud dan Ahmad).

Nabi memberikan peringatan kepada anak-anak yang menghina dan mencela manusia, "Janganlah engkau menampakkan celaan kepada saudaramu, karena Allah akan belas kasih kepadanya dan akan mengujimu." (HR Turmudzi). Dalam alQuran Allah berfirman, "Wahai orang-orang yang beriman, janganlab suatu kaum mengolok-ngolok kaum yang lain karena boleh jadi mereka (yang diolok-olok) lebih baik dari mereka (yang mengolok-ngolok). Dan jangan pula wanita-wanita (mengolok-ngolok) wanita yang lain (karena) boleh jadi wanita-wanita (yang diolok-olok) itu lebih baik dari wanita (yang mengolok-ngolok)" (QS. Al-Hujurât [49]: 11).

5. Anak Usia Lima Belas sampai Delapan Belas Tahun.

Nabi menganjurkan anak-anak muda untuk memanfaatkan waktu paginya, "Tidur pada waktu shubuh (awal siang) akan mencegah datangnya rizki. "(HR Ahmad). Hadis yang lain,'Rasulullah saw berdoa;'Ya Allab berkabilah untuk umatk.u pada waktu paginya."(HR. Thabrani.). Nabi mengajarkan kepada anak-anak agar percaya diri, makan dari hasil tangannya, menjauhi sifat menunda-nunda dan malas. Nabi bersabda," Sesunggubnya Allab mencintai orang mukmin yang bekerja (kreatif)," (HR. Thabrani). Nabi menetapkan hak anak-anak dalam mencari ilmu dan belajar al-Qur'an. Nabi bersabda,"mencari ilmu itu wajib bagi setiap Muslim, dan orang-orang yang memberikan ilmu kepada selain ablinya (artinya kepada orang yang belum saatnya menerima ilmu tersebut) itu. Seperti orang yang mengalungkan mutiara, Nabi menyuruh anak-anak untuk memilih guru yang saleh. Nabi bersabda,"Seseorang itu tergantung atas agama temannya, bendaklah salah seorang di antara kalian melibat siapa orang yang diajak berteman," (HR. Turmudzi, Abu Dawud dan Ahmad). Seorang guru harus mengamalkan ilmunya dan ucapannya sesuai dengan perbuatannya. Nabi menyuruh anak-anak perempuan untuk menutup auratnya ketika mereka telah baliqh. Dalam al-Quran (QS, Al-Ahzab [33]: 59) Allah berfirman, "Hai Nabi, katakanlah kepada istri-istri orang-orang mukmin: hendaklah mereka mengulurkan jilbabnya ke selurub tubub mereka".

\section{SIMPULAN}

Penerapan pola asuh orang tua dalam keluarga berkontribusi terhadap perilaku anak negatif, misalnya sikap agresif maupun positif, penuh kasih sayang. Berarti setiap pola asuh memuat pesan-pesan moral, adab, watak, sikap dan akhlak tertentu. Karena setiap pola asuh memiliki kelemahan dan kelebihannya 
masing-masing maka orang tua hendaknya tidak secara total menerapkan salah satu pola asuh, juga tidak secara eklektif memilih beberapa pola asuh berdasarkan kecenderungan subjektifnya. Dalam perspektif pendidikan akhlak, hendaknya semua pola asuh dilandasi oleh; 1) rasa kasih sayang terhadap anakanak; 2) mendoakan kepada anak-anak; 3) menanamkan rasa syukur; 4) melatih bersedekah kepada fakir miskin; 5) senang berbagi kebahagiaan dengan orang lain; 6) selalu jujur dalam berkata maupun berbuat (tidak berdusta kepada orang lain); 7) berpegang teguh pada ajaran agama/Tuhan; 8) bersikap tegas namun tetap sopan dan beradab; 9) senantiasa memanfaatkan waktu luang secara bermakna dan 10) selalu memperhatikan hak-hak orang lain di samping sabar dalam menjalankan segala bentuk kewajiban/peraturan yang ditetapkan kepadanya. Sepuluh dimensi akhlakiah ini tergambar dalam pola asuh Rasul Muhammad SAW saat mendidik anak, cucu serta seluruh umatnya.

\section{DAFTAR PUSTAKA}

Backman, CW. 1986. Socialpsychologycal view of Educational. New York: Harcourt Brace Jovanovich.

Baron, Robert A. 1977. Human Aggression. New York: Plenum Press.

Gerungan. 1987. Psikologi Sosial. Bandung: PT Erasco.

Sutari I. Barnadib. 1986. Pengantar Pendidikan Sistimatis. Yogyakarta: FIP IKIP Yogyakarta.

Spock, B. 1982. Membina Watak Anak. Terjemahan Wunan. JK. Jakarta: Penerbit Gunung Jati.

Stewart \& Koch. 1983. Chidren Development Throught Adolescence. Canada: John Wiley and Sons, Inc.

Yusuf, Syamsu. 2005. Psikologi Perkembangan Anak \& Remaja. Bandung: CV. Rosda karya.

Hafizh, Muhammad Nur Abdul. 1998. Mendidik Anak Bersama Rasulullah. Bandung: CV Al Bayan. 